第60回 日本視能矯正学会

シンポジウム II 高齢者の斜視を考える

高齢者の斜視に対する視能評価

- Sagging eye syndrome と

眼球運動神経麻痺との相違点を中心にー

岡 真由美 ${ }^{1)} \cdot$ 星原 徳子 ${ }^{2)} \cdot$ 河原 正明 ${ }^{2)}$

1)川崎医療福祉大学リハビリテーション学部視能療法学科

2) 河原眼科クリニック

\title{
Clinical Evaluation of Strabismus in Elderly Individuals with Emphasis on the Differences between Sagging Eye Syndrome and Ocular Movement Nerve Paralysis
}

\author{
Mayumi Oka ${ }^{1)}$, Noriko Hoshihara-Fukuda ${ }^{2)}$, Masaaki Kawahara ${ }^{2)}$ \\ ${ }^{1)}$ Kawasaki University of Medical Welfare, Faculty of Rehabilitation, Department of Orthoptics \\ ${ }^{2)}$ Kawahara Eye Clinic
}

要 約

超高齢社会において、加齢性斜視である sagging eye syndrome（以下SES）が注目されている。 本研究では、SESの鑑別疾患としてあげられる眼球運動神経麻痺との相違を検討し、画像診断の前 に視能訓練士が行うべき病態分析と視能評価について述べた。

1. 年歯令区分別の斜視の種類

年齢区分が高くなるほど共同性斜視が減少し、非共同性斜視（眼球運動障害を伴う斜視とする） が増加した。非共同性斜視のうち、年齢区分が高くなるにつれて増加傾向にあったのは滑車神経麻 痺、SES、Parkinson 病関連疾患であった。

2. SES と眼球運動神経麻痺における複視の発症様式

SESは滑車神経麻痺および外転神経麻痺よりも発症から初診までの期間が長く、複視の発症日が 不明確であった。

3. SES と眼球運動神経麻痺の眼位・眼球運動

別冊請求先（テ701-0193）岡山県倉敷市松島 288

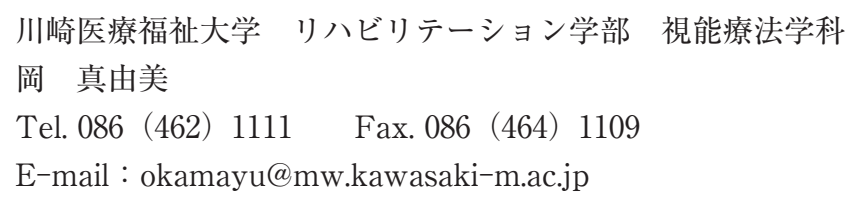

Key words : 加齢性斜視、sagging eye syndrome、眼球運動神経麻痺、回旋偏位 age-related strabismus, sagging eye syndrome, ocular movement nerve paralysis, cyclodeviation 
内斜視を伴うSES は外転神経麻盘よりも斜視角が小さく、わずかな上斜視および回旋偏位を 伴っていた。上斜視を伴うSESは下転眼に外回旋がみられた。滑車神経麻瘦では健眼固視のとき外 回旋が上転眼にみられたが、麻痺眼固視のとき一定の傾向がなく、両者を回旋眼で評価することは 困難であることがわった。

高齢者の斜視ではSESおよびその合併例が多い。SES と眼球運動神経麻痺との区別は困難である ことから、病歴聴取と患者の観察、回旋偏位の検出が有用であり、むき運動検查と合わせて総合的 に評価することが重要である。

\section{Abstract}

In a rapidly aging society, sagging eye syndrome (SES, also called age-related strabismus) has received attention recently. In this study, we examined the pathological differences between SES and ocular movement nerve paralysis for their differential diagnoses. Herein, we described the pathological analysis and clinical evaluation that should be performed by an orthoptist before diagnostic imaging.

1. Types of strabismus classified by age

With advancing age, concomitant strabismus decreased and incomitant strabismus increased. Among the types of incomitant strabismus, trochlear nerve paralysis, SES, and Parkinson's disease and related disorders tended to increase with age.

2. Patterns of diplopia onset in patients with SES and ocular movement nerve paralysis

Compared to patients with trochlear and abducens nerve paralysis, patients with SES had a longer interval between diplopia onset and first consultation, and the timing for their diplopia onset was less clear.

3. Eye position and eye movement in SES and ocular movement nerve paralysis

SES presented with esotropia had a smaller angle of ocular deviation than those with abducens nerve paralysis as well as comorbid small-angle hypertropia and excyclotropia. The hypotropic eye was excyclotropic in SES with hypertropia. In patients with trochlear nerve paralysis, excyclotropia was observed in the hypertropic eye when fixating with the healthy eye. However, no particular tendency was observed when fixating with the paralyzed eye. This suggested that distinguishing SES and trochlear nerve paralysis could be difficult in patients with a cyclodeviated eye.

SES and SES-associated diseases are common in the elderly with strabismus. Although it is difficult to differentiate SES and trochlear or abducens nerve paralysis, detailed history taking, patient examination, and detection of cyclodeviation could be useful. In addition, it is important to conduct a comprehensive evaluation including the version eye movement test.

\section{I 。緒言}

医療技術が急速に進歩する中、日本人の平均 寿命は過去最高記録を更新し続けている。加齢 による身体機能の低下や障がいは否応なしにも たらされ、視能矯正の領域では加齢性斜視であ るSagging eye syndrome (以下SES) が注目 されている。

近年、MRIによる画像診断の技術向上と研究
の進歩は目覚ましく、病態評価における有用性 が示されている。その一方で、画像診断にかか る患者の時間的、経済的負担は大きく、画像診 断の前に視能訓練士が可能な限り病態分析と視 能評価を行い、患者の負担軽減を図ることが課 題である。視能評価は病態評価にとどまらず、 健康な「視る」生活を維持させるための評価で なくてはならない。 本研究では、第 1 に年齢区分別の斜視の種類、 
第 2 にSES と眼球運動神経麻疩における複視の 発症様式、第 3 にSES と眼球運動神経麻疩の眼 位・眼球運動について述べる。

\section{II . 対象および方法}

対象は 2015 年 5 月から 2019 年 7 月に河原眼科 クリニックを受診した斜視例 340 例であった。 年齢区分は、厚生労働省が推進する健康日本 $21^{1)}$ にしたがい、25歳から44歳を壮年群、45歳 から 64歳を中年群、65歳以上を高年群とした。

眼位は交代プリズム遮閉試験 (Alternate prism cover test: 以下 APCT) おょびDuane's parallax test ${ }^{9)}$ で測定した。parallax testは微 細な眼位ずれの検出に有用で、交代遮閉に伴う 視標の動きの方向を患者に問うものである。患 者が観察した視標の動く方向は眼球運動の方向 を示し、検者は視標の動きを中和するプリズム 度数を求める。例えば遮閉を右眼から左眼に移
したとき、右眼での視標の見え方が「下に動い た」と言えば、右眼は「上から下に眼球運動し た」ことがわかり、右眼上斜と判定する。した がってプリズムは右眼基底下方とし、視標の動 きが中和された度数を求める。回旋偏位は、大 型弱視鏡を用いて測定した。上下斜視に対して はBielschowsky 頭部傾斜試験 (Bielschowsky head tilt test: 以下BHTT）を行った。

本研究は、川崎医療福祉大学倫理委員会の審 査（16-023）を経て実施した。

\section{III. 結果}

1 年齢区分別の斜視の種類

1）年齢区分別の斜視のタイプ（図 1)

年齢区分が高くなるほど共同性斜視の割合は 減少し、非共同性斜視（眼球運動障害を伴う斜 視とする）の割合が増加した。

2）年齢区分別の非共同性斜視の原因（図2）

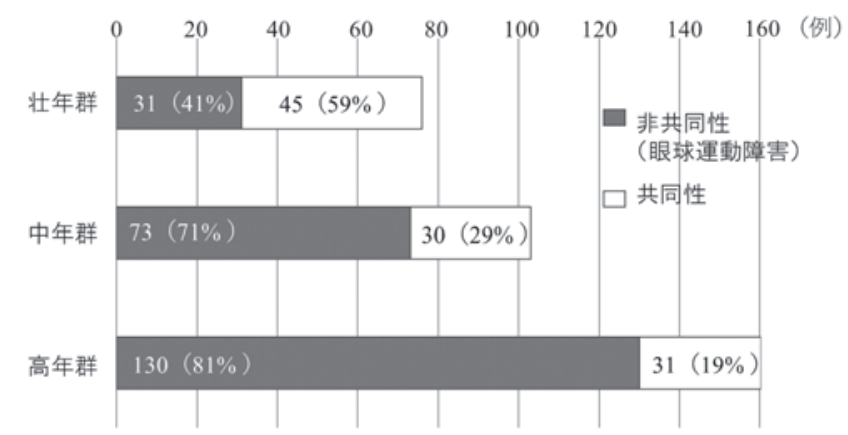

図 1 年齢区分別の斜視のタイプ

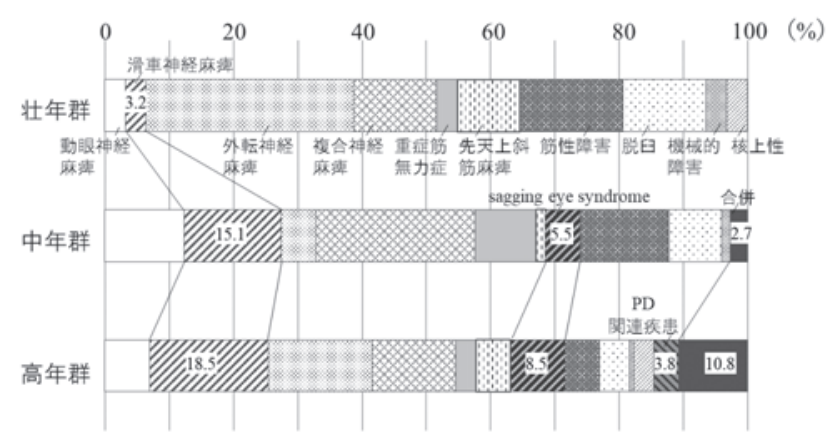

図2 年齢区分別の非共同性斜視の原因 
年齢区分が高くなるにつれて増加傾向にあっ たのは滑車神経麻痺であった。中年群から高 年群にかけてみられたのはSESと各種疾患の 合併例であった。合併例では、SESとの合併が 多かった。高年群でみられたのはParkinson 病 (Parkinson disease: 以下 PD) 関連疾患で、進 行性核上性麻痺が含まれた。

$2 \mathrm{SES}$ と眼球運動神経麻疩における複視の発 症様式

高年群のうちSESは8例で、SES と鑑別が必 要な滑車神経麻㿁は 13 例、外転神経麻瘦は 13 例であった。

SES と滑車神経麻疩、外転神経麻痖における 複視の発症様式を表 1 に示す。SESは複視発症 から初診までの期間の中央值が 2 年で、複視の 発症日が明確なケースは少なかった。患者が複 視に気づいたきっかけは、車の運転やゴルフ、 白内障術後であった。

滑車神経麻瘏と外転神経麻痺は複視発症から 初診までの期間の中央值がそれぞれ6 日、17日
であった。また複視は発症日が明確で、歩行時 や外傷後、帯状疮疹の発症後など急性発症で あった。

3 SES と眼球運動神経麻疩の眼位 - 眼球運動 高年群におけるSES、滑車神経麻疩、外転神 経麻痺例のうち、大型弱視鏡による回旋偏位の 測定が可能だったのは24例であった。内訳は、 内斜視を伴う SES (以下 E-SES) 2例、上斜視 を伴う SES（以下 H-SES）5例、滑車神経麻疩 13例（末梢血管性 6例、外傷性 2 例、炎症性 1 例、原因不明 1 例)、外転神経麻瘒 4 例（末梢血 管性 2 例、脳腫瘍 1 例、原因不明 1 例）であっ た。

1） E-SES と外転神経麻痺の比較（表2）

$\mathrm{APCT}$ での水平偏位は E-SESの方が、外転神 経麻痺よりも小さい傾向であった。両者ともに 遠見偏位の方が近見偏位より大きく、上下偏位 はなかった。

大型弱視鏡検査の水平偏位は APCT と同様、 E-SESの方が外転神経麻痷よりも小さかった。

表1. SES と神経麻痺の発症様式

\begin{tabular}{|c|c|c|c|}
\hline & $\begin{array}{c}\text { 発症から初診 } \\
\text { までの期間 } \\
\text { の中央値 }\end{array}$ & $\begin{array}{l}\text { 複視発症日 } \\
\text { 明確な例(\%) }\end{array}$ & $\begin{array}{l}\text { 発症 } \\
\text { 状況等 }\end{array}$ \\
\hline$(n=8)$ & 2 年 & $1 / 8(12.5)$ & $\begin{array}{l}\text { 徐々, 白内障術後 } \\
\text { 遠見(運転, ゴルフ })\end{array}$ \\
\hline $\begin{array}{l}\text { 滑車神経（ } n=13 ） \\
\text { 麻痺 }\end{array}$ & 17日 & $12 / 13(92.3)$ & $\begin{array}{l}\text { 急性(歩行時など) } \\
\text { 外傷後, 原因疾患あり }\end{array}$ \\
\hline $\begin{array}{l}\text { 外転神経 }(n=13) \\
\text { 麻瘦 }\end{array}$ & 6日 & $11 / 13(84.6)$ & \\
\hline
\end{tabular}

表2. E-SES と外転神経麻痺の眼位

\begin{tabular}{|c|c|c|c|c|c|c|c|c|}
\hline & \multirow[b]{3}{*}{ 症例 } & \multicolumn{4}{|c|}{$\operatorname{APCT}(\triangle)$} & \multirow{2}{*}{\multicolumn{3}{|c|}{ 大型弱視鏡 $\left({ }^{\circ}\right)$}} \\
\hline & & \multicolumn{2}{|c|}{ 水平 } & \multicolumn{2}{|c|}{ 上下 } & & & \\
\hline & & 遠見 & 近見 & 遠見 & 近見 & 水平 & 上下 & 外回旋 \\
\hline \multirow[t]{2}{*}{ E-SES } & 1) & +10 & +8 & 0 & 0 & +10 & 0 & 2 \\
\hline & 2) & +4 & 0 & 0 & 0 & +5 & 1 & 4 \\
\hline \multirow{4}{*}{$\begin{array}{l}\text { 外転神経 } \\
\text { 麻痺 }\end{array}$} & 1) & +20 & +6 & 0 & 0 & +15 & 1 & 0 \\
\hline & 2) & +18 & +12 & 0 & 0 & +14 & 0 & 0 \\
\hline & 3) & +10 & +3 & 0 & 0 & +10 & 0 & 0 \\
\hline & 4) & +8 & 0 & 0 & 0 & +13 & 0 & 0 \\
\hline
\end{tabular}


上下偏位は E-SES 1例、外転神経麻疩 1 例にみ られた。E-SESの他の1例は、水平第 2 眼位で 上下偏位がみられた。外回旋偏位は E-SESでは 2例ともにみられ、外転神経麻瘏ではみられな かった。

2) H-SES と滑車神経麻痺の比較

表3にH-SES と滑車神経麻痺の斜視角を示 す。APCTによる両者の水平偏位は遠見で同程 度であった。近見斜視角は滑車神経麻疩で外斜 傾向であった。上下偏位および外回旋偏位の中 央值は両者ともに同程度であった。BHTTが陽 性の症例は H-SESで1例のみであった。

表 4 に H-SES と滑車神経麻痺の外回旋眼を示 す。H-SESでは固視眼を上転眼のみで測定して おり、外回旋がみられたのは全例下転眼であっ た。滑車神経麻痺は固視眼を下転眼 (健眼) と したとき、外回旋がみられたのは全例が上転 眼（麻痺眼）であった。一方、固視眼を上転眼 （麻痺眼）としたとき、外回旋がみられたのは 上転眼 (麻疩眼) 4 例、下転眼 (健眼) 5 例、両 眼 4 例と一定の傾向がなかった。

\section{IV. 考按}

SESは、加齢に伴う筋間結合織である外直筋上直筋（以下 LR-SR）バンドの菲薄化により、 外直筋プリーが下垂して生じる微小な内斜視ま たは上下回旋斜視、あるいは両者の合併をいう 2)。SESは眼窩プリー以外にも眼周囲の軟部組 織の変化を呈するため、baggy lid（囊状眼瞼）、 superior sulcus deformity（上眼瞼のくぼみ変 形)、腱膜性眼瞼下垂などの外眼部異常を伴う 2)。複視を主訴とする症例のうちSESは、50歳 未満で $4.7 \%$ 、90歳以上で $60.9 \%$ に増加すると 報告されており ${ }^{3)}$ 、これまで原因不明とされて いた高齢者の複視にはSESが含まれていた可 能性がある。今回、高齢者の斜視の種類を統計 し、SES と滑車神経麻痺または外転神経麻疩と の鑑別のための視能評価法について検討した。

SESの他に年齢区分が上がるにつれ増加する 斜視の原因に滑車神経麻痖と PD 関連疾患がみ られた。眼球運動神経麻痺を年代別にまとめ た報告では、滑車神経麻㾝では60歳以上より も20歳から 39歳で多かった ${ }^{4)}$ 5) これは、診 療所では壮年者に多い外傷性が少なく、高齢者

表3.H-SES と滑車神経麻疩の斜視角 (中央值)

\begin{tabular}{|c|c|c|c|c|c|c|}
\hline & \multicolumn{4}{|c|}{$\operatorname{APCT}(\triangle)$} & \multirow{3}{*}{$\begin{array}{c}\text { 外回旋 } \\
\left({ }^{\circ}\right)\end{array}$} & \multirow{3}{*}{$\begin{array}{c}\text { BHTT } \\
\text { 陽性 } \\
\text { (例) }\end{array}$} \\
\hline & \multicolumn{2}{|c|}{ 水平 } & \multicolumn{2}{|c|}{ 上下 } & & \\
\hline & 遠見 & 近見 & 遠見 & 近見 & & \\
\hline$(\mathrm{n}=5)$ & 0 & 0 & 3 & 5 & 3 & $1 / 5$ \\
\hline 滑車神経麻瘒 $(n=13)$ & 0 & -8 & 6 & 5 & 3 & $13 / 13$ \\
\hline
\end{tabular}

表4.H-SES と滑車神経麻痺の外回旋偏位眼

\begin{tabular}{|c|c|c|c|c|c|}
\hline & & \multirow[t]{2}{*}{ 固視眼 } & \multicolumn{3}{|c|}{$\begin{array}{l}\text { 大型弱視鏡 } \\
\text { 回旋眼 (例) }\end{array}$} \\
\hline & & & 上転眼 & 下転眼 & 両眼 \\
\hline H-SES & $(n=5)$ & 上転眼 & 0 & 5 & 0 \\
\hline \multirow{2}{*}{$\begin{array}{l}\text { 滑車神経 } \\
\text { 麻瘦 }\end{array}$} & $(n=13)$ & 下転眼 (健眼) & 13 & 0 & 0 \\
\hline & & 上転眼 (麻疸眼) & 4 & 5 & 4 \\
\hline
\end{tabular}


にみれる末梢血管性が多いためと考える。ま た、PDは比較的頻度の高い神経変性疾患であ り、広範囲の運動症状 (安静時振戦、筋強剛、 無動・寊動、姿勢保持障害による前傾姿勢）と 非運動症状（気分障害、認知機能低下、感覚障 害、自立神経障害、幻視など）によって特徵付 けられる ${ }^{6)}$ ○Dの視機能に関する報告では 58 歳から 88 歳にみられ、50\%に上下斜視、輻湊 不全、上転障害などを伴っており、頻度は高い が見逃されやすい7)。これらの疾患は、概診に よって疾患の想起が可能で、病歴聴取と視能検 査を通して、眼瞼の状態、顔貌、頭位、姿勢な ど患者の観察を行うことが重要である。高齢者 にみられる斜視の種類とその評価方法を理解す ることは、視能矯正の第一歩である。

SESは加齢に伴い徐々に進行するため、初期 には複視が間欠性であり、初発時の記憶が不明 瞭である場合が多い8)。また白内障術後に各眼 の視力が良好になったため複視に気付く場合が あり、今回の症例においても同様であった。こ れは、滑車神経麻瘏と外転神経麻痺の発症様 式と異なる点であった。病歴聴取においては 4W1Hにしたがい発症様式に留意しながら筋道 だった質問をし、以後の検査計画の立案に役立 つよう情報収集を行う。

E-SES と外転神経麻瘏の斜視角を比較する と、E-SESでは大型弱視鏡で外回旋とわずか な上下偏位がみられ、外転神経麻瘏との鑑別点 となる可能性があった。外回旋は筋間結合織の LR-SRバンドの菲薄化による外直筋プリーの下 垂と外直筋の下方偏位による ${ }^{2)}$ 。上下偏位はこ の両眼の対称性変化では生じないが、わずかな 非対称性変化で生じた可能性がある2)。E-SES と外転神経麻痺との区別のため、微小な上下偏 位の検出には大型弱視鏡または parallax testが 有用であった。回旋偏位の検出には、大型弱視 鏡に代わり Maddox rod test、視力不良例では 眼底カメラや光干涉断層計により他覚的方法を 活用することも可能である。ただし、Maddox rod testの定量は5ㅈテップであり、微小な変 化を捉えにくく留意する必要がある。

$\mathrm{H}-\mathrm{SES}$ と滑車神経麻痺では、正面視での水 平・上下・回旋偏位に顕著な差がなかった。回
旋偏位は滑車神経麻㾝で上転眼、H-SESで下 転眼にみられた。これは両者を区別する臨床所 見であると述べられている2)。しかし、滑車神 経麻痺では回旋眼が固視眼によって異なってい た。これは回旋偏位が優位眼・非優位眼の影響 を受けること和、成人でも感覚適応 ${ }^{11)}$ 12) による 回旋融像が発達していることが要因と考えられ ている。すなわち、SES と滑車神経麻疩の区別 に抢いて、回旋眼が上転眼か下転眼かで判断す ることは困難と考える。

BHTTの陽性は滑車神経麻痖でみられた。し かし、BHTTは複数筋麻痺での鑑別ができにく いこと、交代性上斜位や斜偏位などで陽性とな ることなどから、上斜筋麻疩に特有でないと報 告されており ${ }^{13)}$ 14)、慎重な評価が必要である。 したがって、H-SESと滑車神経麻疩との区別 は、病歴聴取・患者の観察、むき眼位・むき運 動検査との総合評価が重要である。

\section{V. 症例提示}

89歳の男性。

主訴 : 複視の増大、車の運転が困難

現病歴：86歳、近医で白内障に対して眼内レ ンズ挿入術を施行され、術後より複視を自覚し た。外転神経麻痺と診断され、プリズム療法を 受けた。89歳、近医より河原眼科クリニックを 紹介された。

視診：わずかな右への斜頸がみられた（図3a）。 歩行時の異常なし。

初診時所見: 視力は右 $(1.0 \times \mathrm{IOL} \mathrm{Cyl}-$ $\left.1.75 \mathrm{D} \mathrm{Ax} 80^{\circ}\right)$ 、左 $(0.9 \times \mathrm{IOL} \mathrm{Cyl}-1.75 \mathrm{D}$ $\left.\mathrm{Ax} 80^{\circ}\right)$ であった。前医で処方された眼鏡には 両眼 $3 \Delta$ 基底外方プリズムが組み达まれていた。 眼位は遠見で $12 \Delta$ 内斜視、近見で $6 \Delta$ 内斜位 一斜視であった。定量されたプリズム装用下で 複視は中和された。このことから両眼視機能の 基礎が確認でき、プリズム眼鏡の適応と判断し た。

むき運動検査では、左眼外転障害、両眼上転 障害がみられた（図3b）。Hess赤緑試験でも、 左眼外転障害とともむき筋の右眼内直筋過動が みられた（図 $4 a ） 。 大$ 型弱視鏡では他覚的斜視 


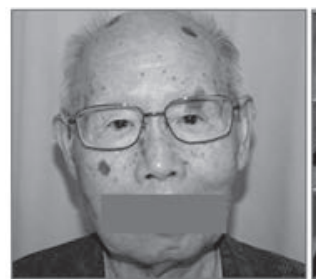

a

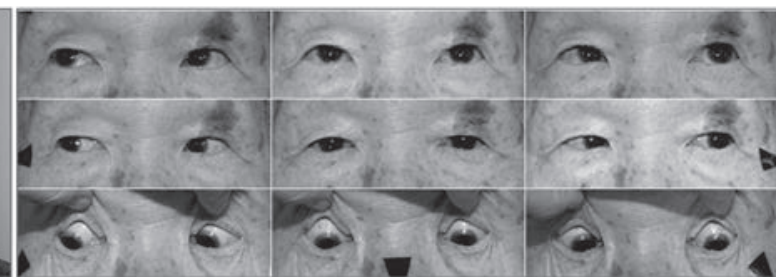

$\mathrm{b}$

図3 9方向眼位

a. わずかな右への斜頸がみられた。b. 左眼外転障害と両眼上転障害がみられた。

a
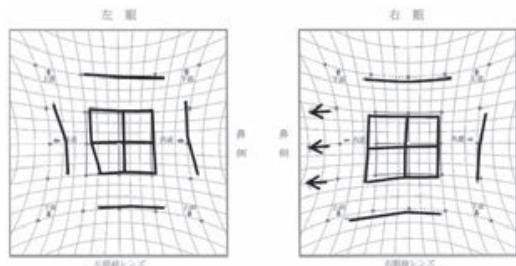

右眼固視

b

\begin{tabular}{|c|c|c|}
\hline 右方 $15^{\circ}$ & 正面 & 左方 $15^{\circ}$ \\
\hline \multirow[t]{2}{*}{+7} & $+11^{\circ}$ & $+19^{\circ}$ \\
\hline & & $\mathrm{R} / \mathrm{L}^{\circ}$ \\
\hline L) EXT4 $4^{\circ}$ & L) $\operatorname{EXT} 4^{\circ}$ & L) EXT5 \\
\hline
\end{tabular}

図4古き運動

a. Hess 赤緑試験で左外転神経麻瘏を示した。 b. 大型弱視鏡での水平むき眼位で左外転神経 麻痺を示した。

左方 $15^{\circ}$ で上下偏位と外回旋偏位がみられた。 EXT: 外方回旋偏位

角 $+11^{\circ}$ 、自覚的斜視角 $+11^{\circ}$ 、左外回旋 $4^{\circ}$ で あった。水平斜視角は左方視で増大し、左外転 神経麻疩の所見を示した（図 $4 \mathrm{~b}) 。$ 左方 $15^{\circ}$ での 上下偏位と外回旋がみられ、SESが疑われた。

さらに、治療法の選択と予後予測のため融像 の状態を測定し、安定した感覚性融像 ${ }^{15)}$ と幅の ある運動性融像 $\left(-5^{\circ} \sim+20^{\circ}\right)$ をみとめた。 日常視での両眼視機能の評価のため Bagolini 線 条鏡での融像野を測定した（図5)。前医で処 方されたプリズム眼鏡下では融像野がみられな かったが、膜プリズムを追加することで正面視 を含む $8^{\circ} \sim 20^{\circ}$ の融像野が得られ、日常生活 の不自由さが改善した。

その後の眼窩 MRI画像で、両側LR-SRバン ドの菲薄化と外直筋の上部耳側傾斜がみられ (図6)、SES と診断された。

症例の問題リストは\#1両）近視性乱視、

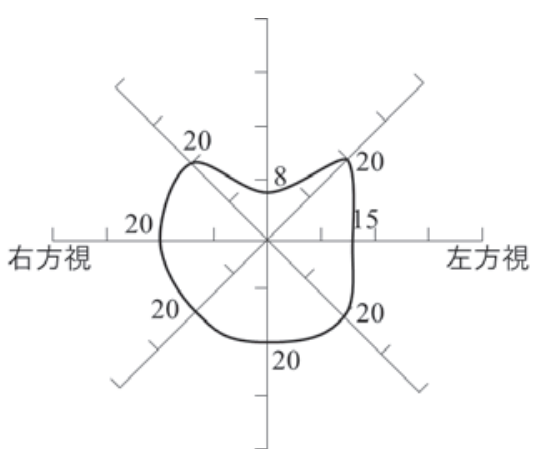

図5 Bagolini 線条鏡での融像野 $\left({ }^{\circ}\right)$

自鏡装用下では融像野はみられなかった。自 鏡に $5 \Delta$ 基底外方プリズムを付加し、8〜 $20^{\circ}$ の融像野が出現した。

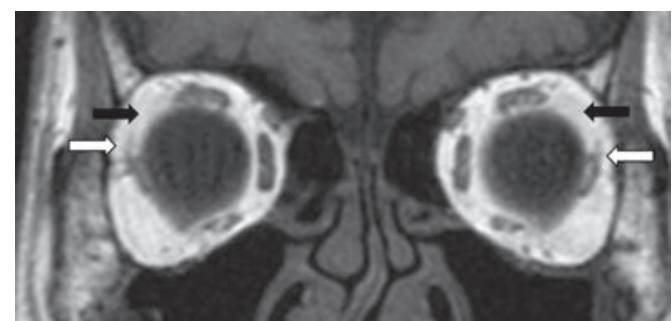

図6 眼窩MRI冠状断

両側LR-SRバンドの菲薄化（黒矢印）と両側 外直筋の上部耳側傾斜（白矢印）がみられた。

\#2 両）IOL抻入眼、\#3 両眼視機能の基礎あ り、\#4 網膜正常対応、\#5 内斜視、\#6 外回旋 斜視、\#7 左外転神経麻痺、\#8 Sagging eye syndrome、\#9 頭位異常（右への斜頸）であっ た。視能矯正としてプリズム療法を計画した。 


\section{VI. 結論}

高齢者の斜視ではSESおよびその合併例が多 い。SES と滑車神経麻疩または外転神経麻疩の 鑑別のための視能評価には病歴聴取と観察、回 旋偏位の検出が有用であり、むき運動検査と合 わせて総合的に評価することが重要である。ま た日常生活に活かす視能評価により、視る生活 の支援に努める必要がある。

稿を終えるにあたり、研究にご協力いただき ました河原眼科クリニック橋本真代氏に深謝申 し上げます。

利益相反 : 利益相反公表基準に該当なし

\section{参考文献}

1) https://www.mhlw.go.jp/wwwl/topics/ kenko21_11/s0.html

2 ) Chaudhuri Z, Demer JL: Sagging eye syndrome: connective tissue involution as a cause of horizontal and vertical strabismus in older patients. JAMA Ophthalmol 131: 619-625, 2013

3 ) Goseki T, Suh SY, Robbins L, Pineles SL, Velez FG, Demer JL: Prevalence of sagging eye syndrome in adults with binocular diplopia. Am J Ophthalmol 209: 55-61, 2019

4) Akagi T, Miyamoto K, Kashii S, Yoshimura $\mathrm{N}$ : Cause and prognosis of neurologically isolated third, fourth, or sixth cranial nerve dysfunction in cases of oculomotor palsy. Jpn J Ophthalmol 52: 32-35, 2008

5 ) 宮本和明: 眼球運動神経麻痺. 眼科 52: 789-
796, 2010

6 ) Ekker MS, Janssen S, Seppi K, Poewe W, de Vries NM, Theelen T, et al: Ocular and visual disorders in Parkinson's disease: Common but frequently overlooked. Parkinsonism Relat Disord 40: 1-10, 2017

7 ) 阿曾沼早苗, 豊岡圭子, 佐古田三郎, 不二門 尚, 西田幸二: パーキンソン病の視機能につ いての検討. 眼臨紀 8: 81-87, 2015

8 ）大平明彦: 50 歳以上の高齢者にみられた加齢 による斜視の長期観察。日眼会誌 119: 619624, 2015

9 ) Duane A: Some new tests for insufficiencies of the ocular muscles, together with a system of abbreviations suitable for notetalking. NY Med J. 50: 113-118, 1889

10）大平明彦：上斜筋麻痺における他覚的外方回 旋偏位と優位眼の影響。臨眼 71: 995-999, 2017

11）大平明彦: 加齢に関連して発症した小角度の 上下斜視における外方回旋偏位と優位眼. 日 眼会誌 123: 161-166, 2019

12）堀川晶代, 平井美恵, 河野玲華, 長谷部 聡, 大 月 洋: 上斜筋麻痺の回旋偏位に対する感覚適 応. 臨眼 54: 1447-1450, 2000

13) Kushner BJ: Errors in the three-step test in the diagnosis of vertical strabismus. Ophthalmology 96: 127-132, 1989

14）大月 洋: Bielschowsky 頭部傾斜試験 覚書 2. 静的眼球反対回旋との関係.日視会誌 38 : 35-40, 2009

15）岡 真由美: fusion lock training. 若山曉美, 長谷部佳世子, 松本富美子, 保沢こずえ, 梅田 千賀子 (編)：視能訓練学. 348-350. 医学書 院, 東京, 2018 